The ministry is right to wish to buy its defence equipment as cheaply as possible, but is wrong to advance, for the purposes of a monopoly investigation, the argument that there have to be two potential British suppliers of everything it may choose to buy. The monopolies commission might just as sensibly have invited the defence ministry to follow British Telecom in listing overseas suppliers among those competing for its business.

This is the nub of the difficulty the British government has now created for itself. Although GEC is among the largest of British companies, it is tiny by the yardsticks of its direct competitors elsewhere, with annual sales roughly one sixth of the new combination of GE and RCA in the United States. Yet what the past few years have shown, specifically in the development of digital switching systems but generally, in electronics as a whole, is that the costs of launching new projects are invariably huge. Moreover, speed is of the essence; there are no prizes for being second. The point has probably now been reached at which only huge companies with long pockets can hope successfully to launch new projects that are technically interesting and likely to change the world in important and profitable ways. The sad history of System X shows the penalties of spending too little too late.

The British government, which for most of its spell in office has stuck to the principle that governments should not secondguess entrepreneurs, has on this occasion allowed itself to make industrial policy by default, by tamely accepting what the majority of the monopolies commission had to say (there is a dissenting minority report). The wisdom of this easy course will never be directly tested, for there may not now be a chance to tell what a slightly larger company than GEC might be able to accomplish by way of technical innovation. But there can be no doubt of its inequity; under British as distinct from US law, there is no way in which such decisions, however unfair they may be to shareholders of companies such as GEC, can be tested in the courts.

The moral in this sad tale is that all governments should take this opportunity to look again at their arrangements for regulating monopolies. In Britain, it is plainly an expensive luxury that companies are prevented from doing what makes economic sense for the sake of giving the defence procurement people the choice of several competitors for defence contracts; if that is what they believe they need, they should be prepared to throw the bidding open to all comers. In most European countries, there is an urgent need to ask how national legslation on monopolies can be squared with the general doctrine that trade flows freely across what used to be national frontiers. And to the extent that the United States now feels as much threatened by Japan as by the danger that its own companies might rig the domestic and overseas markets to their own advantage, there is a strong case for asking that the full rigours of the anti-trust legislation should be softened in the interests of the ultimate beneficiaries - those who buy the products of the new technology.

\section{Nuclear regulation}

\section{The International Atomic Energy Agency has handled Chernobyl deftly. What next?}

Tuss is bound to be more than an unusually formative year for the International Atomic Energy Agency (IAEA) at Vienna; the next few weeks could tell just what the agency's future holds. This is the season at which the agency's board of governors holds its annual meeting, in recent years a more or less routine affair concerned with the difficulty of recruiting enough skilled inspectors to operate the safeguards system and with the constant anxiety about the budget (which amounted to $\$ 87$ million last year, modest for a UN agency). The difference this year is Chernobyl and its consequences, both immediate and for the future development of nuclear energy.
How has the agency, by instinct (and formal constitution) a sponsor of nuclear energy, handled the past few weeks? First, it has done well to ensure a reasonably regular and frequent flow of information about the damaged reactor at Chernobyl. After ten tense days from 26 April, pressure from the agency seems to have been instrumental to that end, while its constitution as an international agency appears to have made it acceptable to the Soviet authorities and other governments in Eastern Europe as a repository of information. More recently, the agency has done a valuable job in persuading member states to give some thought to the steps that need taking to keep each other alert to the risks of cross-border pollution by radioactive materials; in due course, these arrangements may have the force of a convention. Later this month, the agency hopes to go one important step further with the consultation that has been arranged at which the Soviet side says it will tell all about the accident at Chernobyl.

Sponsor of nuclear power though the agency may be, it plainly recognizes that its sponsorship will lead nowhere if ordinary people in its members states are left with the dark suspicion that each nuclear power station is potentially as much a source of catastrophe as was Chernobyl. That is the only sensible view to take. The agency's problem, in the years that lie ahead, will be to blend realism and optimism in a convincing way. That will be a formidable task.

\section{Deeper pork barrels}

Is the academic community in the United States too exercised by Congress's wayward ways?

For the past few years, the US Congress seems to have become an embarrassment to many in the academic community who are resentful of the notion that research funds should be distributed by congressional whim rather than by the more familiar techniques of judicious peer review and solemn committee discussion. Last year, Cornell University turned down the offer of a research grant it had not sought and in the process won the approval of those who believe that the award of money for research is a process far too serious to be left to the hunches of people whose only achievement is merely to have run successfully for public office. Most other recipients of these funds, which amount in total to rather more than $\$ 10$ million in any year, but probably less than $\$ 50$ million, have kept the money but have not advertised the fact. This year, in the rush to finish off the new tax bill and the budget for the financial year beginning in just six weeks, it is inevitable that many proposals for the support of specified research projects will finish up as amendments which are added almost surreptitiously to legislation making its way through the Congress for other purposes.

The US research community will do itself very little good if it takes too prim a view of these developments. Naturally, it would indeed be disastrous for the pattern of research in the United States if any but a small proportion of the funds available for research were to escape the standard system of scrutiny, or if the only means open to researchers for recruiting support for their work required, in the first instance, close personal acquaintance with an elected member of the Congress. But the sprinkling of research grants so far awarded from the pork barrel into which Congress from time to time dips hardly amounts to a substantial threat to the system as its stands. To the extent that most of the grants awarded in this informal way stem from the personal concern (however self-interested) of a congressman for a local academic institution, their frequency may even be regarded as a welcome sign that legislators are not as indifferent to the needs of the research community as they are sometimes said to be. Provided that the frequency of these grants does not get out of hand (in which case the spending agencies would no doubt decline to accept the instructions foisted upon them), there is a case for regarding them as a welcome way of bridging gaps in the orthodox system. Is not plurality still a benefit? 